TECHNICAL PAPER

\title{
HOMOGENEOUS Pinus SP. PARTICLE BOARDS REINFORCED WITH LAMINATED COMPOSITE MATERIALS
}

Doi:http://dx.doi.org/10.1590/1809-4430-Eng.Agric.v36n3p 558-565/2016

\section{ANDRÉ L. CHRISTOFORO ${ }^{1}$, MARIA F. DO NASCIMENTO ${ }^{2}$, TULIO H. PANZERA ${ }^{3}$, SÉRGIO L. M. RIBEIRO FILHO ${ }^{4}$, FRANCISCO A. R. LAHR}

\begin{abstract}
This study aimed to evaluate the mechanical performance of laminated composite materials (fiberglass, carbon, sisal, palm fiber) in epoxy matrix as reinforcement in wood particleboards of Pinus sp. with bicomponent polyurethane resin from castor oil. Modulus of elasticity (MOE) and modulus of rupture (MOR) were investigated using a three-point bending test. Single-layered laminated plates were used to reinforce traction of specimens obtained from boards. MOE and MOR of materials developed without reinforcements exceeded limits in ABNT standards both NBR 12810-2:2002 and A208.1:199, proving therefore their feasibility. In all investigated cases, inclusion of reinforcements led to higher values for both MOE and MOR. Composites in fiberglass presented the best results.
\end{abstract}

KEY WORDS: Particleboard, laminated composites, structural reinforcement.

\section{PAINÉIS HOMOGÊNEOS DE PARTÍCULAS DE Pinus sp. REFORÇADOS POR MATERIAIS COMPÓSITOS LAMINADOS}

RESUMO: Este trabalho objetivou avaliar o desempenho mecânico do emprego de materiais compósitos laminados (fibras de vidro; carbono; sisal; piaçava) em matriz epóxi, como reforço em painéis de partículas de madeira Pinus sp. com resina poliuretana bicomponente, derivada de óleo de mamona. Foram investigados, com o uso do ensaio de flexão estática a três pontos, o módulo de elasticidade (MOE) e o módulo de ruptura (MOR). Os compósitos laminados foram fabricados com camada única, reforçando à tração os corpos de prova obtidos dos painéis. Os resultados do MOE e do MOR dos materiais desenvolvidos sem a inclusão dos reforços superaram os limites contidos nos documentos normativos ABNT NBR 14810-2:2002 e A208.1:199, comprovando a viabilidade dos materiais elaborados. Em todos os casos investigados, a inclusão dos reforços conduziu a valores superiores, tanto para o MOE quanto para o MOR, apresentando os compósitos em fibras de vidro os melhores resultados.

PALAVRAS-CHAVE: Painéis de partículas, compósitos laminados, reforço estrutural.

\section{INTRODUCTION}

Several researches have been developed on manufacturing wood particleboards. They aimed to verify the feasibility of board elaboration by certain stipulated experimental levels and factors (YEMELE et al., 2008; SHI et al., 2005). Adhesives based on urea-formaldehyde are the most commonly used (AKGÜLA and ÇAMLIBELB, 2008; SAFFIAN et al., 2011).

\footnotetext{
${ }^{1}$ Engenheiro Civil, Prof. Doutor, Departamento de Engenharia Civil (DECiv), Universidade Federal de São carlos (UFSCar) / São Carlos - SP, Fone: (16) 3306-6828, christoforoal@y ahoo.com.br

${ }^{2}$ Arquiteta, Pesquisadora Doutora, Laboratório de Madeira e de Estruturas de Madeira (LaMEM) da Escola de En genh aria de São Carlos, Universidade de São Paulo (EESC/USP) / São Carlos - SP, fati@ sc.usp.br

${ }^{3}$ Engenheiro Mecânico, Prof. Doutor, Departamento de Engenharia Mecânica (DEMEC), Universidade Federal de São João del-Rei (UFSJ) / São João del-Rei - MG, tuliopanzera@ufsj.edu.br

${ }^{4}$ Engenheiro Mecânico, Bacharel, Departamento de En genh aria Mecânica (DEMEC), Universidade Federal de São João del-Rei (UFSJ) / São João del-Rei - MG, tuliopanzera@ufsj.edu.br

${ }^{5}$ Engenheiro Civil, Prof. Doutor, Departamento de Engenharia de Estruturas (SET), Escola de En genharia de São Carlos, Universidade de São Paulo (EESC/USP) / São Carlos - SP, frocco@sc.usp.br 
One aspect to be considered in particleboard manufacturing is the use of products that pollute the environment. Mainly through gas emissions. Thus, the development of new products is necessary. As the study proposed by BRADI et al. (2006). They evaluated the influence of mixture of vegetal oil in polyurethane matrix in mechanical strength of wood fiberboards. According to the analysis, the conclusion is that it is possible to use vegetal oil in polyurethane matrix in 35:65 ratio (by weight) for making wood fiberboards.

SILVA and LAHR (2007) evaluated the production of homogeneous particleboards in Amazon with low and medium density (Erisma uncinatum, Nectranda lanceolata, Erisma sp). Boards were made with nominal thickness of $10 \mathrm{~mm}$ and nominal density of $0.75 \mathrm{~g} \mathrm{~cm}^{-3}$. Using $10 \%$ of polyurethane resin derived from castor oil and particles with lengths from $0.02 \mathrm{~mm}$ to $6 \mathrm{~mm}$, under pressing conditions with temperature $90^{\circ} \mathrm{C}, 40 \mathrm{MPa}$ and time of $10 \mathrm{~min}$. In assessments performed according to the Brazilian norm ABNT NBR14810, wood particleboards of Nectaranda lancelota presented the highest levels in bending static strength. They were higher than the limit set by the normative document.

FIORELLI et al. (2011) developed boards of agglomerated particles with sugarcane bagasse and polyurethane resin derived from castor oil. They investigated the following properties: density, swelling in thickness, water absorption and modulus of elasticity and rupture in static flexion. Results indicated the fabricated materials as high-density, recommended for ind ustrial use. Showing efficiency of polyurethane resin based on castor beans as adhesive.

PAES et al. (2011) evaluated the effect of pressure (2.0, 3.0, $3.5 \mathrm{MPa})$ and temperature (50, $60,90^{\circ} \mathrm{C}$ ) combination in particleboards with residues of wood Pinus elliottii and polyurethane resin derivate from castor oil in variable responses: density, swelling in thickness and water absorption (0-2h, 2-24h, 0-24h); elasticity and static bending modulus, screw pull-off and perpendicular traction strength. The conclusion is that the combinations: $3.0 \mathrm{MPa}$ and $90^{\circ} \mathrm{C}$ and $3.5 \mathrm{Mpa}$ and $60^{\circ} \mathrm{C}$ showed the best results. Proving that the pressing temperature is the most important variable regarding the quality (finish) of the prepared boards.

SARTORI et al. (2012) evaluated the mechanical performance of eucalyptus wood boards and sugarcane bagasse particleboards $(10 \mathrm{~mm}$ thick) with bicomponent polyurethane resin derived from castor oil as an alternative solution to the lateral closing system of the cattle trap of beef cattle management. Modulus of elasticity and static bending of the produced particleboards presented average values equal to $2898 \mathrm{MPa}$ and $22.60 \mathrm{MPa}$. In short, the obtained physical and mechanical properties proved the efficiency of the structural model proposed in this application.

A possible alternative used in improving mechanical properties in boards is the incorporation of reinforcements by composite materials.

CASSIDY (2002) observed mechanical behavior of OSB boards after hurricanes. Flaws were noted in the preached connection of boards. In the research, an OSB board was designed with polymers reinforced with fiberglass (PRF) in the most affected areas. Tests showed that mechanical strength increased about 39\%, quadrupling energy dissipation capacity.

FONSECA, COSTA and DIAS (2011) evaluated the influence in mechanical performance of strengthened plywood board (14 mm thick) reinforced (longitud inal and transverse directions) with a layer of laminated composite material of fiberglass fixed in upper and lower sides. Boards with reinforcement in longitudinal direction show MOR average value equal to $65.40 \mathrm{MPa}$, and 43.70MPa for the unreinforced. In transversal direction of reinforce use, the average value of the strength modulus in static flexion was equal to $51.97 \mathrm{MPa}$, and 29.78MPa for unreinforced boards. In summary, the authors conclude that reinforcement insert (in both directions) provided increase in MOR values of boards. It also reduced the water absorption and humidity of fabricated materials.

EDIANE (2011) studied physical and mechanical characteristics of parallel blade boards (LVL) reinforced with one or two fiberglass layers. Boards were made with laminates of $P$. elliottii, $1.5 \mathrm{~mm}$ thick and connected with resin based on phenol-formaldehyde. Elasticity modulus in static flexion (flatwise position) of boards reinforced by fiber glass laminated composite materials and 
epoxy matrix showed values varying in the range of $70328 \mathrm{kgf} \mathrm{cm}^{-2}$ [6899 MPa] to $102832 \mathrm{kgf} \mathrm{cm}^{-2}$ [10087 MPa]. For static bending modulus, the average values vary from $1023 \mathrm{kgf} \mathrm{cm}^{-2}$ [118 MPa] to $2489 \mathrm{kgf} \mathrm{cm}^{-2}$ [244 MPa]. The author reaches this conclusion, among others, that the reinforcement with a layer significantly influenced MOE values and the reinforcement of two layers influenced MOR values.

OSTAPIV (2011) produced SARRAFEADOS eucalyptus boards with reinforcement of giant bamboo blades (Dendrocalamus Giganteus). Results showed an increase of mechanical strength in static flexion of laminated boards with both sides. Showing, with bamboo blades insertion, a ductile behavior. It was different from the fragile behavior from the unreinforced board.

According to Associação Brasileira da Indústria de Painéis de Madeira (ABIPA) (Brazilian Association of Wood Board Industry) (ABIPA, 2006), Brazil is one of the most advanced countries in manufacture of particleboards. The country has the largest number of state-of-the-art factories. The annual production currently is $612.000 \mathrm{~m}^{3}$. It represents a very low percentage to the world production, considering the timber potential of the country and technologies installed.

The aim of this study considers the positive aspects of the current production of particleboards in Brazil, and the need for studies that allow the use of alternative solutions, as reinforcement. Thus, with the support of norms ABNT NBR 14810:2002 and A208. 1:1999, this study aimed to evaluate the influence of laminated composites reinforced by natural fibers (palm fiber and sisal fiber) and synthetic fibers (glass and carbon fibers) in boards of homogeneous particles of wood Pinus sp. in static flexion of strength and hardness properties.

\section{MATERIAL AND METHODS}

The sawdust of Pinus sp. wood was obtained from the company Madeireira Expansão Ltda (São Carlos city, São Paulo State). Factors at fixed levels used in board production were wood species (Pinus sp.), rein type (polyurethane derived from castor oil), nominal density $\left(0.80 \mathrm{~g} \mathrm{~cm}^{-3}\right)$, nominal thickness $(10 \mathrm{~mm})$, particle humidity content $(5 \%)$, resin percentage $(10 \%)$, time spent in pressing cycle $(10 \mathrm{~min})$, pressing temperature $\left(90^{\circ} \mathrm{C}\right)$, pressing pressure $(4 \mathrm{MPa})$ and particle size (up to $2.8 \mathrm{~mm}$ ).

Procedures used in board manufacture were prepared on the premises of the Laboratory of Timber and Timber Structures (LaMEM) of the Department of Structural Engineering (SET), in the College of Engineering of São Carlos (EESC/ USP), Universidade de São Paulo - USP (University of São Paulo - USP). According to these procedures, it should be noted:

- Addition of $10 \%$ of bicomponent polyurethane resin (pre-polymer and polyol in the ratio $1: 1$ ). According to instructions of the manufacturer, it was initially added and mixed to the substrate the content that corresponds to a part of the polyol. Then, the content corresponding to a part of the prepolymer. This procedure provided good resin homogenization to the substrate and prevented expansion reactions.

- Pressing cycle: it consisted in applying constant pressure of $4 \mathrm{MPa}$ for 3 minutes. Then, the relief of press pressure for 30 minutes, and subsequent use of 4MPa pressure for 6 minutes and 30 seconds, for total pressing time of 10 minutes. This procedure was used for making all boards, and it was observed that there were no formation of bubbles and breakages in the boards.

- Pressing temperature: the temperature used was $90^{\circ} \mathrm{C}$, avoiding bubble formation and leading to board production with improved uniformity.

Five particleboards were produced with wood species Pinus sp., with $40 \mathrm{~cm} \mathrm{x} 40 \mathrm{~cm}$ dimensions. In each board, 10 specimens were removed. They were all destined to statistic bending essays to obtain values of elasticity modulus (MOE) and strength modulus (MOR). Dimensions were $20 \mathrm{~cm} \times 5 \mathrm{~cm} x 1 \mathrm{~cm}$. Of the fifty specimens, ten were reinforced with laminated composites with fiberglass (bidirectional tissue), ten were reinforced with laminated composites of sisal fibers (unidirectional tissue), and ten were reinforced with laminated composites of palm fiber (unidirectional tissue). The remaining ten were not reinforced (reference). 
Regarding laminated composites, the matrix used was epoxy resin, provided by the company Resiqualy® (São Paulo city, São Paulo State). Glass and carbon fibers used were provided by the company Fibrex (Louveira city, São Paulo State), both had bidirectional fabrics and basis weight of $50 \mathrm{~g} \mathrm{~m}^{-2}$. The company DM Piaçava Brasil (Ilhéus city, São Paulo State) provided palm fibers. They have average diameter varying in the range of $0.8 \mathrm{~mm}$ to $1.6 \mathrm{~mm}$. Sisal fibers were provided by the company Sisalsul (São Paulo city, São Paulo State) with average diameter of $2.9 \mathrm{~mm}$.

Composites were made by manual laminated process. In particular, these reinforced by natural fibers (unidirectional) were a priori laminated in a metal structure on a glass plate coated with release fabric (Figure 1), which allowed alignment of fibers.

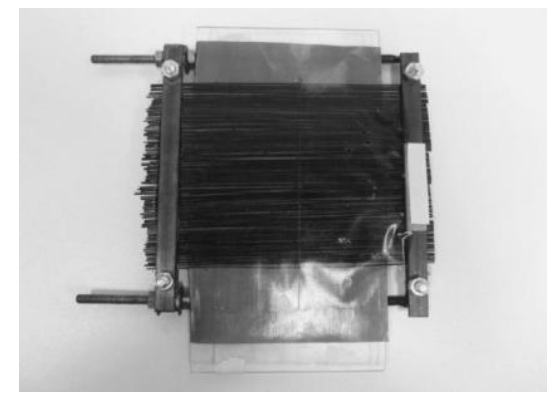

FIGURE 1. Laminating process of composite material reinforced by palm fibers.

In laminated composites of synthetic fibers, lamination was made directly on the fabric (carbon and fiberglass bidirectional mesh). The equipment used in natural fibers (unidirectional) was not necessary. After laminating (single blade), the composites of both fibers were brought to a vacuum pump (pressure of $0.8 \mathrm{bar}$ ) for the removal of internal bubbles and excessive resin. Subsequent to this process, the composite specimens remained in a tightly closed container for a period of seven days for complete resin curing process. Subsequent to curing, a small amount of resin was added over the surface of the sheets only for its fixation in specimens of fabricated boards, which were tested in statistic flexion after curing time of the resin used in the fixation.

After specimens were prepared for the flexion test, those that received reinforcements had their fibers positioned in the tensioned region (bottom). The aim was to increase strength values and rigidity of manufactured materials.

The confidence interval between rates was used to verify statistical equivalence of MOE and MOR values of specimens of materials fabricated with and without reinforce, expressed by [eq. (1)] (MONTGOMEY, 2005). Thus, $\mu$ is the mean difference, $\bar{x}_{m}$ is the arithmetic mean of differences, $n$ is the sample size, $S_{m}$ is sample standard deviation of the differences and $t_{\alpha / 2, n-1}$ is the value tabulated for " $t$ " Student distribution with $n-1$ as degrees of freedom and $\alpha$ as significance level.

$$
\bar{x}_{m}-t_{\alpha / 2, n-1} \cdot S_{m} / \sqrt{n} \leq \mu \leq \bar{x}_{m}+t_{\alpha / 2, n-1} \cdot S_{m} / \sqrt{n}
$$

It should be noted that the confidence interval was evaluated at the significance level of 5\%. In addition, that the Anderson-Darling normality test was used to verify the normality in distribution of strength and hardness values of the tested materials. Both were performed with the support of Minitab® software version 14. According the normality test formulation, also evaluated at significance level of 5\%, P-value higher than 5\% implies that the distribution is normal. Regarding confidence interval (IC $(\mu)$ ), if P-value found is higher than significance level $(0.05)$ or if zero belongs to IC, this implies that confronted groups (two by two) have statistically equivalent means, and not equivalents in the opposite case.

In order to ind icate possible differences between values of MOE and MOR of specimens with and without reinforces, and with reinforces compared by synthetic and natural fibers, the method of least squares was used, expressed by [eq. (2)] (CHRISTOFORO, 2011). The aim is to determine the best coefficient $(\alpha)$ that minimizes the difference between values of MOE and MOR. 
For analysis of MOE and MOR, the variable $f$ contained in [eq. (2)] in the mechanical property (MOE or MOR) of unreinforced specimens. While variable $f^{*}$ represents the mechanical properties of materials with reinforcement. When comparing MOE and MOR between boards reinforced by natural fibers and those reinforced by synthetic fibers, variable $f$ assumes results of mechanical properties from the sisal reinforcement (comparing to palm fiber) and related to the reinforcement with carbon fibers (comparing to fiberglasss).

$$
f(\alpha)=\frac{1}{2} \sum_{i=1}^{n}\left(f_{i}-\alpha \cdot f_{i}^{*}\right)^{2}
$$

\section{RESULTS AND DISCUSSION}

Table 1 shows mean values $(\bar{x})$, standard deviations $(S d)$ and variation coefficients $(C v)$ referring to elasticity modulus (MOE) and strength modulus (MOR) in static flexion of materials fabricated and tested. SR is the unreinforced boards (reference), RFV and RFC are the boards reinforced by fiberglass and carbon laminated composites, respectively. RFP and RFS are the materials reinforced by palm fiber and sisal fibers laminated composites, respectively.

TABLE 1. Values of MOE (MPa) and MOR (MPa) of reinforced and unreinforced materials.

\begin{tabular}{ccccccccccc}
\hline \multirow{2}{*}{ Stat. } & \multicolumn{2}{c}{ SR } & \multicolumn{2}{c}{ RFV } & \multicolumn{2}{c}{ RFC } & \multicolumn{2}{c}{ RFP } & \multicolumn{2}{c}{ RFS } \\
$\bar{x}(\mathrm{MPa})$ & 3651 & 24.5 & 7643 & 57.1 & 6247 & 55.3 & 3972 & 39.5 & 4210 & 49.6 \\
\cline { 2 - 11 }$S d$ & 397.58 & 3.56 & 997.22 & 9.21 & 924.08 & 8.20 & 560.90 & 6.37 & 519.14 & 9.30 \\
$C v(\%)$ & 10.89 & 14.53 & 13.05 & 16.13 & 14.79 & 14.83 & 14.12 & 16.13 & 12.33 & 18.75 \\
\hline
\end{tabular}

The values of elasticity modulus of the studied boards (Table 1) were both higher than what is recommended by the American norm A208.1:1999 (2750 MPa).

According to the Brazilian norm ABNT NBR 14810-2:2002, MOR values must be at least equal to $18 \mathrm{MPa}$. In Table 1, breakage modulus in static bending for both unreinforced and reinforced specimens showed values higher than those stipulated by the Brazilian norm did.

Average values of MOR of strengthened plywood boards with $14 \mathrm{~mm}$ thick, manufactured by FONSECA, COSTA and DIAS (2011) with blades of reinforce oriented in longitudinal and transverse direction were $65.40 \mathrm{MPa}$ and $51.97 \mathrm{MPa}$. Particleboards reinforced with fiberglass in the present study showed MOR average value of $57.10 \mathrm{MPa}$. It is found among the study results of FONSECA, COSTA and DIAS (2011), however, that the authors fabricated wood strengthened plywood boards, while those of the present study were made of wood particles.

Parallel blade boards developed by EDIANE (2011) showed average MOE values ranging from $6899 \mathrm{MPa}$ to $10087, \mathrm{MPa}$ and $118 \mathrm{MPa}$ to $244 \mathrm{MPa}$ to the range of mean values of MOR. In the present study, particleboards reinforced with fiberglass showed MOE and MOR values equal to 7643Mpa and 57.10 MPa, respectively. It is noteworthy that the discrepancies (superiority of LVL) found in values of mechanical properties confronted are explained essentially by the nature of boards.

Sugarcane particleboards $10 \mathrm{~mm}$ thick were developed and characterized in the study of SARTORI et al. (2012). They were fixed in a eucalyptus wood structure and resulted in a modular system. They showed average values of MOE and MOR equal to $2898 \mathrm{MPa}$ and $22.60 \mathrm{MPa}$, respectively. Soft body test evaluated the mechanical strength of the modular system to the impact. According to the results of this essay, the largest displacements measured in the impact load direction showed acceptable magnitudes (within the limits set by the norm). Thus, the system is suitable for beef cattle management center. According to MOE and MOR values of particleboards (with and without reinforce) developed in this study, it is possible to observe that they showed potential for use also in application as those tested in the study of SARTORI et al. (2012). 
Table 2 shows results (P-values) of Anderson-Darling normality tests for values of MOE and MOR of fabricated materials. Proving to be normal the data distribution in all experimental conditions investigated, by presenting in each case $\mathrm{P}$-value higher than 0.05 .

TABLE 2. Results of Anderson-Darling normality test.

\begin{tabular}{ccc}
\hline \multirow{2}{*}{ Condition } & \multicolumn{2}{c}{ P-value: Anderson-Darling test } \\
& MOE & MOR \\
\hline SR & 0.976 & 0.609 \\
RFV & 0.424 & 0.340 \\
RFC & 0.565 & 0.531 \\
RFP & 0.509 & 0.664 \\
RFS & 0.402 & 0.400 \\
\hline
\end{tabular}

Tables 3 and 4 show results of confidence intervals $(\mathrm{CI}((\mu))$ for MOE and MOR, respectively. They aim to assess if the reinforce provided equivalent values $(\mathrm{Eq})$ or not $(\mathrm{NEq}) \mathrm{when}$ compared to unreinforced conditions, as well as verification of statistic equivalence between boards reinforced by fiberglass and between boards reinforced with natural fibers.

TABLE 3. Results of hypothesis tests for elasticity modulus of in static reflection (MOE).

\begin{tabular}{ccc}
\hline Relation & CI $(\boldsymbol{\mu})$ & Condition \\
\hline $\mathrm{SR} \times \mathrm{RFV}$ & $-4739.94 \leq \mu \leq-3245.54$ & $\mathrm{NEq}$ \\
$\mathrm{SR} \times \mathrm{RFC}$ & $-3289.56 \leq \mu \leq-1903.32$ & $\mathrm{NEq}$ \\
$\mathrm{SR} \times \mathrm{RFS}$ & $-997.30 \leq \mu \leq-120.60$ & $\mathrm{NEq}$ \\
$\mathrm{SR} \times \mathrm{RFP}$ & $-782.59 \leq \mu \leq 139.19$ & $E q$ \\
$\mathrm{RFV} \times \mathrm{RFC}$ & $489.23 \leq \mu \leq 2303.37$ & $\mathrm{NEq}$ \\
$\mathrm{RFS} \times \mathrm{RFP}$ & $-272.67 \leq \mu \leq 747.16$ & $E q$ \\
\hline
\end{tabular}

TABLE 4. Results of hypothesis tests for strength modulus in static flexion (MOR).

\begin{tabular}{ccc}
\hline Relation & CI $(\boldsymbol{\mu})$ & Condition \\
\hline SR $\times$ RFV & $-39.50 \leq \mu \leq-25.75$ & NEq \\
SR $\times$ RFC & $-37.00 \leq \mu \leq-24.65$ & NEq \\
SR $\times$ RFS & $-32.07 \leq \mu \leq-18.21$ & NEq \\
SR $\times$ RFP & $-19.94 \leq \mu \leq-10.04$ & NEq \\
RFV $\times$ RFC & $-6.42 \leq \mu \leq 10.04$ & $E q$ \\
RFS $\times$ RFP & $2.55 \leq \mu \leq 17.75$ & NEq \\
\hline
\end{tabular}

Results of the coefficient relation ( $\alpha$ ) by least squares (Equation 2) between MOE and MOR of specimens and with and without reinforce and between synthetic fiber and natural fiber reinforces are shown in Table 5.

TABLE 5. The $\alpha$ coefficients obtained by least square method.

\begin{tabular}{|c|c|c|c|}
\hline Relation & Coef. $(\alpha)$ & Relation & Coef. $(\alpha)$ \\
\hline $\mathrm{MOE}_{\mathrm{RFV}}=\alpha \cdot \mathrm{MOE}_{\mathrm{SR}}$ & 2.09 & $\mathrm{MOR}_{\mathrm{RFV}}=\alpha \cdot \mathrm{MOR}_{\mathrm{SR}}$ & 2.31 \\
\hline $\mathrm{MOE}_{\mathrm{RFC}}=\alpha \cdot \mathrm{MOE}_{\mathrm{SR}}$ & 1.67 & $\mathrm{MOR}_{\mathrm{RFC}}=\alpha \cdot \mathrm{MOR}_{\mathrm{SR}}$ & 2.23 \\
\hline $\mathrm{MOE}_{\mathrm{RFP}}=\alpha \cdot \mathrm{MOE}_{\mathrm{SR}}$ & 1.08 & $\mathrm{MOR}_{\mathrm{RFP}}=\alpha \cdot \mathrm{MOR}_{\mathrm{SR}}$ & 1.59 \\
\hline $\mathrm{MOE}_{\mathrm{RFS}}=\alpha \cdot \mathrm{MOE}_{\mathrm{SR}}$ & 1.15 & $\mathrm{MOR}_{\mathrm{RFS}}=\alpha \cdot \mathrm{MOR}_{\mathrm{SR}}$ & 1.97 \\
\hline $\mathrm{MOE}_{\mathrm{RFC}}=\alpha \cdot \mathrm{MOE}_{\mathrm{RFV}}$ & 0.87 & $\mathrm{MOR}_{\mathrm{RFC}}=\alpha \cdot \mathrm{MOR}_{\mathrm{RFV}}$ & 0.95 \\
\hline $\mathrm{MOE}_{\mathrm{RFS}}=\alpha \cdot \mathrm{MOE}_{\mathrm{RFP}}$ & 1.04 & $\mathrm{MOR}_{\mathrm{RFS}}=\alpha \cdot \mathrm{MOR}_{\mathrm{RFP}}$ & 1.23 \\
\hline
\end{tabular}

Regarding MOE of the designed boards, the only non-efficient reinforce solution was related to boards fabricated with palm fiber, which is equivalent to unreinforced condition (Table 3), 
showing coefficient $\alpha$ equal to 0.08 (Table 5). This implies that MOE of materials reinforced with palm fiber were in average only $8 \%$ higher than MOE of unreinforced materials. Reinforces with fiberglass, carbon and sisal provided increases in MOE values of 109\%, 67\% and 15\%, respectively, when compared to elasticity models of unreinforced materials.

MOR of materials with and without reinforce were classified as non-equivalents. MOR of composites fabricated with fiberglass, carbon, palm fiber and sisal were 131\%, 123\%, 59\% and 97\% higher, respectively, to strength modulus in static flexion of unreinforced materials.

Differently than composites reinforced by natural fibers, MOE of materials reinforced by synthetic fibers were considered non-equivalent. MOE of material reinforced with carbon fibers was $13 \%$ lower than those reinforced by fiberglass was.

Differently than composites reinforced by synthetic fibers, MOR of most materials reinforced by natural fibers were considered non-equivalent. MOR of materials reinforced by sisal fibers $23 \%$ higher than strength modulus in static flexion of boards reinforced by palm fiber.

\section{CONCLUSIONS}

Values obtained from MOE and MOR of unreinforced composites were higher than minimum values stipulated by normative documents A208.1:1999 and ABNT NBR 14810-2:2002. This proves the feasibility of materials developed according to the levels of the investigated factor.

In all cases evaluated, the inclusion of laminated composites provided increases in mechanical properties MOE and MOR. The less significant values were originated from materials reinforced with palm fiber and the most significant with fiberglasss.

Among reinforce solutions by synthetic fibers, the ones designed with fiberglasss were more efficient in both elasticity modulus and breakage modulus. This result is interesting since fiberglass has lower commercial value than carbon fiber.

Regarding natural fibers, sisal was more effective than palm fiber, resulting in values equivalent to elasticity modulus and higher than strength modulus in static flexion.

\section{REFERENCES}

AKGÜLA, M.; ÇAMLIBELB, O. Manufacture of medium density fiberboard (MDF) panels from rhododendron (R. ponticum L.) biomass. Building and Environment. Part Special. Jornal of

Building Performance Simulation, Abingdon, v. 43, n. 4, p. 438-443, 2008.

ANSI - AMERICAN NATIONAL STANDARDS INSTITUTE. ANSI A208: 1: Mat-formed wood particleboard: Specification. Gaithersburg, 1999.

ABIPA - ASSOCIAÇÃO BRASILEIRA DA INDÚSUTRIAS DE PAINÉIS DE MADEIRA -

Produtos e Tecnologias. Sobre consumo mundial de aglomerado em 2004/2005. São Paulo. 2006.

Disponível em: <www.abipa.org.br>.

ABNT - ASSOCIAÇÃO BRASILEIRA DE NORMAS TÉCNICAS. NBR 14810. Chapas de madeira aglomerada. Parte I - Terminologia, Parte II - Requisitos e Parte III - Métodos de ensaio. Rio de Janeiro, 2002.

BRADI, K. H.; AMIM, K.A.M.; OTHMAN, Z.; MANAF, H.A.; KHALID, N.K. Effect of filler-tomatrix blending ratio on the mechanical strength of palm-based. Poly mer International,

Chichester. 55. n. 2, p. 190-195, 2006.

CASSIDY, E. D. Development and structural testing of FRP reinforced OSB panels for

disaster resistant construction. 2002. 215f. Dissertação (Mestrado em Civil Engineering) - The University of Maine, Maine, 2002. 
CHRISTOFORO, A. L.; PANZERA, T. H.; BATISTA, F. B.; BORGES, P. H.; ROCCO, F. A. L. Numerical evaluation of the longitudinal modulus of elasticity in structural round timber beams of Eucalyptus genus. Engenharia Agrícola, Jaboticabal, v. 31,p. 1007-1014, 2011.

EDIANE, A. B. Características físico-mecânicas de painéis de lâminas paralelas reforçados com fibra de vidro. 2011. 98f. Dissertação (Mestrado) - Engenharia Florestal, Universidade Federal de Santa Maria, Santa Maria, 2011.

FIORELLI, J.; ROCCO LAHR, F. A.; NASCIMENTO, M F.; SAVASTANO Jr., H.; ROSSIGNOLO, J. A. Painéis de partículas à base de bagaço de cana e resina de mamona produção e propriedades. Acta Scientiarum Technology, Maringá, v. 33, n. 4, p. 401-406, 2011.

FONSECA, C. B.; COSTA, G. F.; DIAS, F. M. Reforço com fibras de vidro em painéis compensados uma alternativa ecológica. Disponível em: <http:// www. aedb.br/seget/artigos11/45214727.pdf>. Acesso em: 20 jan. 2012.

MONTGOMERY, D. C. Design and analysis of 6th ed. experime nts. Arizona: John Wiley \& Sons Inc, 2005.

OSTAPIV, F. Resistência mecânica do material compósito: madeira de eucalipto-lâmina de bambu. 2011. 148 f. Tese (Doutorado) - Faculdade de Engenharia, Universidade Estadual Paulista, Guaratinguetá, 2011.

PAES, J. B.; NUNES, S. T; ROCCO LAHR, F. A.; NASCIMENTO, M. F.; LACERDA, R. M. A. Qualidade de chapas de partículas de pinus elliottii coladas com resina poliuretana sob diferentes combinações de pressão e temperatura. Ciência Florestal, Santa Maria, v. 21, n. 3, p. 551-558, 2011.

SAFFIAN, H. A.; HARUN, J.; THAIR, P. M; ABDAR, K. Feasibility of Manufacturing a Medium Density Fibreboard Made of 4-Year Old Rubber Tree RRIM 2020 Clone. Key Engineering Materials, Uetikon, v. 471, p. 839-844, 2011.

SARTORI, D. L.; CRAVO, J. C. M.; BARRERO, N. G.; FIORELLI, J.; SAVASTANO Jr., H. Painel em madeira de reflorestamento e chapas de partículas para instalações rurais. Floresta e Ambiente, Rio de Janeiro, v. 19, n. 2, p. 171-178, 2012.

SHI, J. L.; ZHANG, S.Y.; RIEDL, B.; BRUNETTE, G. Flexural properties, internal bond strength and dimensional stability of medium density fiberboard panels made from hybrid poplar clones. Wood and Fiber Science, Lawrence, v. 37, n. 4, p. 629-637. Canada. October, 2005.

SILVA, S.; ROCCO LAHR, F. A. Chapas de partículas confeccionadas com resíduos de madeiras tropicais de baixa densidade. Reciclagem de resíduos para a construção civil. Belo Horizonte. Editora da Universidade FUMEC, 2007. cap. 14, p. 343-365.

YEMELE, M. C. N.; BLANCHET, P.; CLOUTIER, A.; KOUBA, A. Effects of bark content and particle geometry on the physical and mechanical properties of particleboard made from black spruce and trembling aspen bark. Forest Products Journal, Madison, v. 58, n. 11, p. 48-56, 2008. 